\title{
Markers of increased cardiovascular risk in patients with chronic kidney disease
}

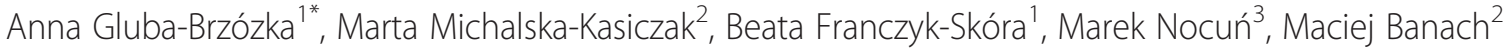 \\ and Jacek Rysz ${ }^{1}$
}

\begin{abstract}
Background: Epidemiological studies have shown that chronic kidney disease (CKD) is an important risk factor for atherosclerosis and cardiovascular disease (CAD). The aim of the study was to determine markers of increased risk of $C A D$ and to achieve a better understanding of agents implicated in the process of atherosclerosis in CKD patients.

Methods: The study group consisted of a total of 139 patients with CKD while the control group comprised 45 healthy volunteers. Concentrations of osteoprotegerin, osteopontin, osteocalcin, matrix $\gamma$-carboxyglutamic acid (Gla) protein (MGP), fetuin A, matrix metalloproteinase-2 (MMP-2), matrix metalloproteinase-9 (MMP-9), tissue inhibitor of metalloproteinase-1 (TIMP-1), tissue inhibitor of metalloproteinase-2 (TIMP-2), ATP binding cassette transporter A1 (ABCA1), ATP binding cassette transporter G1 (ABCG1) and renalase were measured by the ELISA method.

Results: We observed decreased levels of fetuin A (control vs. CKD group: 37.5 vs. $33.2 \mathrm{ng} / \mathrm{ml}, p=0.018$ ), and increased concentrations of osteocalcin (control vs. CKD group: $9.1 \pm 6.0$ vs. $13.6 \pm 10.3 \mathrm{ng} / \mathrm{ml}, p=0.05), \mathrm{MMP}-2(113.1 \pm 75.0$ vs. $166.0 \pm 129.9 \mathrm{ng} / \mathrm{ml}, p=0.045)$, TIMP-2 (22.1 \pm 5.1 vs. $25.4 \pm 7,0 \mathrm{ng} / \mathrm{ml}, p=0.005)$ and renalase $(251.0 \pm 157$ vs. $316.1 \pm$ $155.3 \mathrm{ng} / \mathrm{ml}, p=0.026$ ). In patients with CKD (in comparison to control group), left ventricle ejection fraction: $53.0 \pm$ $3,5 \%$ vs. $48.5 \%, p=0.012$ ) and calcification of the aortic valve ( $9.5 \%$ vs. $39.8 \%, p=0.008$ ) were observed more frequently.

Conclusions: Decreased levels of fetuin A and increased concentration of osteocalcin, renalase, MMP-2 and TIMP-2 suggest that these factors may be involved in the pathogenesis of CAD in patients with CKD. Significantly increased indices of cardiac hypertrophy and its dysfunction in patients with CKD are indicators of pathological mechanisms occurring in cardiovascular system in this group of patients.
\end{abstract}

Keywords: Atherosclerosis, Chronic kidney disease, Calcification, CAD risk

\section{Background}

Chronic kidney disease (CKD) is a significant clinical problem worldwide, with constantly increasing incidence. Epidemiological studies have shown that chronic kidney disease is an important risk factor for cardiovascular disease [1]. Increased coronary artery disease (CAD) risk is associated with increased atherosclerosis, which is more frequent in patients with CKD, especially the dialysis ones, than in the general population. Cardiovascular disease is also the most common cause of mortality in this group of patients [2-4]. According to

\footnotetext{
*Correspondence: aniagluba@yahoo.pl

'Department of Nephrology, Hypertension and Family Medicine, WAM University Hospital of Lodz, Medical University of Lodz, Zeromskiego 113, 90-549 Lodz, Poland

Full list of author information is available at the end of the article
}

Foley et al. [3], the cardiovascular mortality rate in end stage renal disease (ESRD) patients is 10-20 times higher than in the general population after stratification for age, race and gender. At the time of starting renal replacement therapy, the prevalence of CAD is even higher [5-7]. The Hemodialysis (HEMO) Study revealed that ischaemic heart diseases $(20.4 \%)$ as well as cardiac rhythm disorder (10.4\%) were the most common cause of death in dialysed patient [8]. Increased risk of atherosclerosis in these patients is due to the overlapping of traditional risk factors of atherosclerosis with CKD-specific factors (i.e. altered calcium and phosphorus homeostasis, malnutrition, anaemia, hyperhomocysteinaemia, low serum albumin and high fibrinogen levels, as well as oxidative stress and inflammatory state) that further exacerbate 
atherosclerosis in the course of chronic kidney disease $[9,10]$. So far, plaque formation mechanisms in this group of patients are not known, because patients with CKD were often excluded from the study. It seems that greater severity of atherosclerosis in patients with CKD may be associated with impaired lipid and calcium phosphate metabolism. Moreover, arterial calcification, which is an independent risk factor for acute coronary events, is observed even in young patients with CKD. Numerous studies have shown that bone metabolism plays an important role in patients with chronic kidney disease. Osteopontin, osteoprotegerin, fetuin A and matrix $\gamma$-carboxyglutamic acid protein (MGP) are the most important factors in the inhibition of calcifications. Additionally, matrix metalloproteinases (MMPs), which are involved in tissue remodelling, are implicated in the pathogenesis of both cardiovascular disease and kidney disease. Studies have shown that MMP-2, MMP-9 and tissue inhibitors of metalloproteinase -1 (TIMP-1) and -2 (TIMP-2) also play an important role in the pathogenesis of renal damage [11,12].

The aim of the study was to determine markers of increased risk of CAD occurring in CKD patients and to achieve a better understanding of agents implicated in plaque formation in this group of patients. The study may support the identification of individuals who are at high risk of cardiovascular events in order to implement early prevention.

\section{Methods}

The study group consisted of a total of 139 patients with CKD (30 patients with stage I/II CKD, 30 stage III CKD, 30 stage IV CKD and 49 stage V/dialysis) hospitalized in the Department of Nephrology, Hypertension and Family Medicine. The control group consisted of 45 healthy volunteers recruited from patients hospitalized due to causes other than CKD, CAD, hypertension, or diabetes mellitus. All subjects enrolled in this study were informed about its purpose and methodology and signed an informed consent form. The study was approved by the Bioethics Committee of the Medical University of Lodz (no. RNN/ 79/12/KB). The levels of studied proteins and biochemical markers were analysed in blood of all people involved in the study. The study excluded patients with diagnosed cancer, autoimmune diseases and those with a history of myocardial infarction. In the present study, concentrations of proteins involved in the processes of vessel wall calcification and bone metabolism disorders (osteoprotegerin [TECOMedical, no. 8034], osteopontin [RayBiotech, ELH-OPN-001], osteocalcin [TECOMedical, no. 8002], matrix $\gamma$-carboxyglutamic acid protein (MGP) [USCN Life Science, E91477Hu], fetuin A [TECOMedical, no. KT-800]), vascular remodelling (MMP-2, MMP-9, TIMP-1, TIMP-2 [Raybiotech: ELH-MMP2-001, ELH-MMP9-001, ELHTIMP1-001, ELH-TIMP2-001]), cholesterol transport (ATP- binding cassette transporters ABCA1 [Uscn Life Science Inc., E91242Hu], ABCG1 [Uscn Life Science Inc., E91288Hu]) as well as renalase [USCN Life Science, E92845Hu] were measured in order to analyse their influence on cardiovascular risk in CKD patients. Levels of these proteins were determined by the ELISA method according to the manufacturer's instructions.

Levels of biochemical markers such as total cholesterol, low-density lipoprotein (LDL), high-density lipoprotein (HDL), triglyceride (TG), albuminuria, serum calcium and phosphate, Fe, total iron-binding capacity (TIBC), Creactive protein (CRP), alkaline phosphatase activity, creatinine, urea, uric acid, total protein, the level of fibrinogen and D-dimers were also determined. Estimated glomerular filtration rate (GFR-MDRD) was calculated using the Modification of Diet in Renal Disease:

$$
\begin{aligned}
\mathrm{GFR}\left(\mathrm{ml} / \mathrm{min} / 1.73 \mathrm{~m}^{2}\right)= & 186 \times(\text { Creat } / 88.4)^{-1.154} \\
& \times(\text { Age })^{-0.203} \\
& \times(0.742 \text { if female }) \\
& \times(1.210 \text { if black }) .
\end{aligned}
$$

In addition, cardiac echocardiography was performed to assess heart condition and function, the presence of left ventricular hypertrophy and systolic and diastolic function disturbances. The following cardiac indexes were measured: end-systolic interventricular septum thickness (IVSs), end-diastolic interventricular septum thickness (IVSd), left ventricle mass (LV mass), diameter of the left ventricle during systole (LVsys) and diastole (LVdias), left atrial (LA) size, right ventricle (RV) size, aorta, mitral insufficiency (IM), aortic insufficiency (IA), tricuspid insufficiency (IT), early (E) to late (A) ventricular filling velocities ratio (E/A), early transmitral velocity (E'), ratio of early transmitral velocity to mitral annular early diastolic velocity $\left(\mathrm{E} / \mathrm{E}^{\prime}\right)$, deceleration time (DT), ejection fraction (EF\%), valve calcification/fibrosis.

\section{Statistical analysis}

Results were expressed as mean with standard deviation (mean $\pm \mathrm{SD}$ ) for continuous variables with normal distribution or as median with interquartile range (median, 25\%-75\%) in all other cases. The Shapiro-Wilk test was used to verify normal distribution of variables and Levene test to analyse the homogeneity of variance. Standard Student $t$ test for the comparison of data showing no departures from normality, and the non-parametric Mann-Whitney $U$ test for the remaining variables were used. For detailed multiple comparisons (more than two groups) one-way ANOVA with post hoc Tukey tests or non-parametric analysis of variance (Kruskal-Wallis test) with post hoc Conover-Inman tests was used, respectively. The $\chi^{2}$ test of independence was used for the analysis of 
discontinuous variables. Calculations were performed using Statistica ${ }^{\circ} 10$ (StatSoft, Inc., Tulsa, OK, USA).

\section{Results}

The characteristics of studied groups

The average age of patients in the study group (all CKD stages) was $67.1 \pm 12.9$ years and $59.4 \pm 10.0$ in the control group. Men were in the majority in the study groups while women were in the majority in the control group. Diabetes, hypertension, atrial fibrillation, general atherosclerosis and CRP > normal level occurred much more often in the study group than in controls. eGFR-MDRD was also much higher in the control group compared to study group, which is not surprising. No significant differences in the prevalence of obesity and lipid disorders were observed between groups. Demographic data are summarized in Table 1.

\section{The analysis of biochemical parameters}

The analysis of biochemical parameters and echocardiographic indices in study group and controls was also performed (results are summarized in Table 1). Statistically significant differences in the level of $\mathrm{K}^{+}$, haemoglobin, APTT, Fe, LDL, total cholesterol, inorganic phosphate and calcium ions between control and study group were observed. These differences were also noticeable between patients with various CKD stages. Moreover, in CKD patients markers of kidney damage (urea, creatinine, albumin and uric acid) were significantly higher than in controls.

\section{The analysis of echocardiographic indices}

Echocardiographic examination revealed that patients with CKD in comparison with the control group had significantly greater interventricular septal end diastolic dimension, higher left ventricular mass and much larger systolic and diastolic dimensions of the left ventricle, indicating pathological cardiac hypertrophy. These patients also had a significantly greater left atrial dimension. Chronic kidney disease patients were also more likely to have aortic valve calcification and their ejection fraction was significantly lower than in the control group. These observations confirm the adverse effect of renal disease on the cardiovascular system. Although diastolic dysfunction is frequent in patients with CKD, there were no significant differences in its indices, such as $E / A$ and $E / E^{\prime}$ between study and control group.

\section{The analysis of proteins concentrations}

Analysis of the concentrations of proteins associated with bone metabolism revealed no statistically significant differences in the level of osteoprotegerin, osteopontin, or MPG between the control group and patients with chronic kidney disease (all stages). However, it was observed that the concentration of fetuin A in study group was significantly lower than in controls (33.2 vs. $37.5 \mathrm{ng} / \mathrm{ml}$, $\mathrm{p}=0.018$ ) while the level of osteocalcin was significantly higher in patients with CKD $(13.6 \pm 10.3$ vs. $9.1 \pm 6.0 \mathrm{ng} / \mathrm{ml}$, $\mathrm{p}=0.05$ ). Moreover, differences in fetuin $\mathrm{A}$, osteocalcin and osteoprotegerin between groups of patients in various CKD stages were seen. Fetuin A level was highest in patients with mild kidney disease and lowest in dialysis patients $(p=0.002)$; osteocalcin and osteoprotegerin concentrations were highest in dialysis patients and lowest in stages I/II ( $p<0.0001$ and $p=0.005$, respectively). The results are summarized in Table 1 . The study of matrix metalloproteinases and their inhibitors revealed that the level of MMP-2 was much higher in patients with chronic kidney disease in comparison to the control group $(\mathrm{p}=$ $0.045)$ and that statistically significant differences between various stages of $C K D$ were also present $(p=0.008)$. Its highest values were seen in patients with mild kidney disease (stage I/II) then it gradually decreased to reach the lowest value in patients with stage V/dialysis. In case of MMP-9 level only a slight tendency to increase with the worsening of kidney function was noted. Significant differences in proteins concentration between study and control groups were also observed in case of metalloproteinase inhibitor TIMP-2 $(\mathrm{p}=0.005)$ and in the level of TIMP-1 and TIMP-2 between various CKD stages $(\mathrm{p}=0.048$ and $\mathrm{p}=$ 0.003 , respectively). The highest concentrations of TIMP-1 and TIMP-2 were observed in end-stage renal disease patients and the lowest in I/II CKD patients. Furthermore, it was noted that the ratio MMP-2/TIMP-2 was significantly lower in $\mathrm{V} /$ dialysis patients than in patients with mild renal impairment $(\mathrm{p}=0.001)$. The level of renalase also differed significantly between CKD patients and control group $(\mathrm{p}=0.026)$ and between patients with various $\mathrm{CKD}$ stages $(\mathrm{p}<0.0001)$.

\section{The analysis of relationship between protein concentration and biochemical parameters}

The analysis of the relationship between the incidence of both calcification and fibrosis and sex (male), age, level of calcium ions and inorganic phosphate in plasma demonstrated that the risk of mitral valve fibrosis is increased every year 1.15 -fold, the risk of aortic valve fibrosis 1.02fold and the risk of mitral valve calcification by 1.05 , regardless of the concentration of $\mathrm{Ca}^{2+}$, inorganic phosphate level and sex. The results are shown in Table 2.

An analysis of the relationship between concentrations of studied proteins and biochemical parameters was also performed. In the present study an association between serum osteocalcin, osteoprotegerin and fetuin A and the level of inorganic phosphate and between osteoprotegerin levels and CRP was found. Moreover, there was a relationship between fetuin A concentration and the level of calcium ions. In the present study, no association was observed between the concentration of transport proteins 
Table 1 Detailed characteristics of included patients

\begin{tabular}{|c|c|c|c|c|c|c|c|c|}
\hline & Control group $\mathrm{N}=45$ & CKD all stages $N=132$ & $p$ & Stage $I / I I N=30$ & Stage III N= 30 & Stage IV N = 30 & Stage V N $=49$ & $p$ \\
\hline Age & $59.4 \pm 10.0$ & $67.1 \pm 12.9$ & $P<0.0001$ & $69.0 \pm 10.7^{1}$ & $64.5 \pm 14.8$ & $67.9 \pm 14.4$ & $67.3 \pm 12.1^{1}$ & $P=0.005$ \\
\hline Sex, male (\%) & $35.6 \%$ & $56.1 \%$ & $P=0.017$ & $51.9 \%$ & $51.6 \%$ & $36.0 \%$ & $(71.4)^{3}$ & $P=0.0053$ \\
\hline DM (\%) & $11.1 \%$ & $34.1 \%$ & $P=0.003$ & $22.2 \%$ & $32.3^{1}$ & $24.0 \%$ & $46.9^{3}$ & $P=0.003$ \\
\hline Hypertension (\%) & $48.9 \%$ & $88.6 \%$ & $P<0.0001$ & $92.6 \%^{3}$ & $90.3 \%^{3}$ & $92.0 \%^{3}$ & $83.7 \%^{3}$ & $P<0.0001$ \\
\hline Lipid disorders (\%) & $37.8 \%$ & $31.1 \%$ & NS & $25.9 \%$ & $38.7 \%$ & $40.0 \%$ & $24.5 \%$ & NS \\
\hline Obesity (\%) & $33.3 \%$ & $37.1 \%$ & NS & $51.9 \%$ & $45.2 \%$ & $32.0 \%$ & $26.5 \%$ & NS \\
\hline General atherosclerosis (\%) & $6.7 \%$ & $25.0 \%$ & $P=0.008$ & $25.9 \%$ & $16.1 \%$ & $24.0 \%$ & $30.6 \%^{2}$ & $P=0.05$ \\
\hline $\mathrm{K}^{+}[\mathrm{mmol} / \mathrm{l}]$ & $4.27 \pm 0.52$ & $4.64 \pm 0.73$ & $P=0.007$ & $4.59 \pm 0.56$ & $4.31 \pm 0.48$ & $4.62 \pm 0.58$ & $4.9 \pm 0.9^{2,7}$ & $P=0.003$ \\
\hline Haemoglobin [g/dl] & $13.4 \pm 1.5$ & $11.3 \pm 2.0$ & $P<0.0001$ & $11.9 \pm 1.8^{1}$ & $12.6 \pm 1.8$ & $11.2 \pm 2.0^{3}$ & $10.2 \pm 1.6^{3,5,9}$ & $P<0.0001$ \\
\hline Platelet $\left[* 10^{3} / \mu \mathrm{l}\right]$ & $246.3 \pm 70.6$ & $244.1 \pm 95.3$ & NS & $250.4 \pm 108.6$ & $243.2 \pm 71.4$ & $250.0 \pm 120.2$ & $238.0 \pm 89.1$ & NS \\
\hline Monocytes $\left[* 10^{3} / \mu \mathrm{l}\right]$ & $0.44 \pm 0.14$ & $0.49 \pm 0.23$ & NS & $0.49 \pm 0.21$ & $0.50 \pm 0.25$ & $0.57 \pm 0.29$ & $0.46 \pm 0.19$ & NS \\
\hline CRP [mg/l] & $1.7(0.8-4.8)$ & $6.4(2.3-12.4)$ & $P<0.0001$ & $6.4(2.0-12.7)^{1}$ & $3.9(1.9-7.9)$ & $7.6(2.4-18.1)^{2}$ & $7.9(3.4-17.1)^{3}$ & $P<0.0001$ \\
\hline \multirow[t]{2}{*}{$\operatorname{ALP}[\mathrm{U} / \mathrm{I}]$} & $82.2 \pm 34.9$ & $94.5 \pm 55.4$ & NS & $93.3 \pm 32.8$ & $69.2 \pm 31.7$ & $111.8 \pm 101.9$ & $100.8 \pm 40.1^{8}$ & $P=0.004$ \\
\hline & $79.5(59.2-97.0)$ & $86.0(66.0-108.2)$ & & $88.5(66.7-106.6)$ & $67.0(51.0-82.0)$ & $82.0(66.0-107.0)$ & $97.0(73.5-117.0)$ & \\
\hline APTT [s] & $29.4 \pm 3.1$ & $37.4 \pm 11.4$ & $P<0.0001$ & $34.2 \pm 5.1^{1}$ & $35.5 \pm 12.4$ & $40.0 \pm 14.8^{2}$ & $38.2 \pm 10.4^{3}$ & $P<0.0001$ \\
\hline APTT ratio & $0.95 \pm 0.21$ & $1.13 \pm 0.37$ & $P=0.002$ & $1.06 \pm 0.19$ & $1.10 \pm 0.45$ & $1.16 \pm 0.43$ & $1.14 \pm 0.34^{2}$ & $P=0.019$ \\
\hline $\mathrm{Fe}[\mu \mathrm{mol} / \mathrm{l}]$ & $16.9 \pm 6.0$ & $11.5 \pm 6.2$ & $P<0.0001$ & $10.5 \pm 5.7^{2}$ & $15.3 \pm 8.1$ & $11.0 \pm 4.6^{2}$ & $10.4 \pm 5.5^{3,7}$ & $P<0.0001$ \\
\hline TIBC $[\mu \mathrm{mol} / \mathrm{l}]$ & $49.0(45.0-50.0)$ & $44.6(36.5-56.8)$ & NS & $54.2(35.7-61.0)$ & $61.0(52.5-145.5)$ & $45.0(36.5-57.1)^{7}$ & $39.9(34.7-47.6)^{3}$ & $P<0.0001$ \\
\hline Ferritin [ng/ml] & $271.0(8.5-328.0)$ & $228(105.5-680.5)$ & NS & $182.5(66.0-421.2)$ & $134.9(49.0-221.0)$ & $277(153.3-868.0)$ & $444(137.0-844.0)$ & NS $(P=0.097)$ \\
\hline $\mathrm{Ca}^{2+}[\mathrm{mmol} / \mathrm{l}]$ & $2.36 \pm 0.11$ & $2.24 \pm 0.23$ & $P=0.006$ & $2.25 \pm 0.20$ & $2.34 \pm 0.20$ & $2.30 \pm 0.21$ & $2.15 \pm 0.24^{3,9,10}$ & $P<0.0001$ \\
\hline Inorganic P [mmol/l] & $1.12 \pm 0.15$ & $1.49 \pm 0.49$ & $P<0.0001$ & $1.49 \pm 0.66$ & $1.23 \pm 0.24$ & $1.39 \pm 0.36^{1}$ & $1.67 \pm 0.48^{3,8}$ & $P<0.0001$ \\
\hline LDL [mmol/l] & $3.50 \pm 0.76$ & $3.08 \pm 1.66$ & $P=0.001$ & $2.96 \pm 1.08$ & $3.25 \pm 1.68$ & $3.86 \pm 2.77$ & $2.69 \pm 1.01^{2}$ & $P=0.007$ \\
\hline $\mathrm{HDL}[\mathrm{mmol} / \mathrm{l}]$ & $1.34 \pm 0.36$ & $1.26 \pm 0.44$ & NS & $1.37 \pm 0.42$ & $1.21 \pm 0.38$ & $1.38 \pm 0.58$ & $1.16 \pm 0.39$ & NS $(P=0.077)$ \\
\hline $\mathrm{TG}[\mathrm{mmol} / \mathrm{l}]$ & $1.6 \pm 1.0$ & $1.91 \pm 1.00$ & NS (0.063) & $1.7 \pm 0.7$ & $2.3 \pm 1.3$ & $1.8 \pm 1.0$ & $1.8 \pm 0.9$ & NS \\
\hline Total cholesterol [mmol/l] & $5.35 \pm 0.79$ & $5.13 \pm 2.12$ & $P=0.033$ & $5.05 \pm 1.14$ & $5.29 \pm 1.72$ & $6.08 \pm 3.81$ & $@ 4.54 \pm 1.20$ & $P=0.035$ \\
\hline Albumin $[\mathrm{g} / \mathrm{l}]$ & $44.8 \pm 4.6$ & $38.6 \pm 6.1$ & $P<0.0001$ & $38.1 \pm 6.6^{1}$ & $39.5 \pm 6.8$ & $39.4 \pm 6.1$ & $37.9 \pm 5.5^{3}$ & $P=0.002$ \\
\hline \multirow[t]{2}{*}{ Urea $[\mathrm{mmol} / \mathrm{l}]$} & $5.7 \pm 2.0$ & $17.1 \pm 10.3$ & $P<0.0001$ & $14.1 \pm 8.5^{3}$ & $13.0 \pm 12.8^{2}$ & $17.5 \pm 7.2^{3}$ & $21.2 \pm 9.6^{3,9}$ & $P<0.0001$ \\
\hline & $5.1(4.5-6.4)$ & $15.5(9.1-22.5)$ & & $11.5(7.0-24.2)$ & $9.8(6.7-13.5)$ & $17.0(11.7-21.7)$ & $20.6(15.8-25.3)$ & \\
\hline \multirow[t]{2}{*}{ Creatinine $[\mu \mathrm{mol} / \mathrm{l}]$} & $83.1 \pm 14.5$ & $330.1 \pm 234.9$ & $P<0.0001$ & $290.6 \pm 247.7^{3}$ & $159.6 \pm 81.8^{3}$ & $260.2 \pm 139.5^{3}$ & $502.5 \pm 228.2^{5,9}$ & $P<0.0001$ \\
\hline & $82.0(75.0-92.0)$ & $264(131.7-470.5)$ & & $227(109-415)$ & $137(113-174)$ & $232(172.5-300)$ & $497(329-677)^{3}$ & \\
\hline Total protein [g/l] & $69.5 \pm 3.9$ & $66.8 \pm 10.0$ & NS & $69.2 \pm 10.5$ & $63.7 \pm 9.9$ & $70.7 \pm 9.8$ & $65.4 \pm 9.2$ & NS $(P=0.084)$ \\
\hline Uric acid [ $\mu \mathrm{mol} / \mathrm{l}]$ & $305.0 \pm 83.9$ & $416.2 \pm 128.3$ & $P<0.0001$ & $442.8 \pm 122.8^{3}$ & $418.3 \pm 117.7^{2}$ & $459.8 \pm 134.7^{3}$ & $375.7 \pm 126.5$ & $P<0.0001$ \\
\hline eGFR MDRD & $74.0(65.2-83.5)$ & $21(12.2-42.0)$ & $P<0.0001$ & $25.0(14.7-53.2)^{3}$ & $42.0(28.0-55.0)^{1}$ & $21.4(14.9-29.0)^{3}$ & $12.0(8.0-16.0)^{3,4,9}$ & $P<0.0001$ \\
\hline
\end{tabular}


Table 1 Detailed characteristics of included patients (Continued)

\begin{tabular}{|c|c|c|c|c|c|c|c|c|}
\hline IVsd [mm] & $13.6 \pm 1.9$ & $15.0 \pm 2.6$ & $P=0.009$ & $14.1 \pm 1.8$ & $14.7 \pm 2.5$ & $14.1 \pm 2.1$ & $16.3 \pm 2.9^{3,4,10}$ & $P<0.0001$ \\
\hline IVss [mm] & $15.1 \pm 1.4$ & $15.5 \pm 2.1$ & NS & $16.0 \pm 2.1$ & $15.4 \pm 1.9$ & $15.0 \pm 2.2$ & $15.5 \pm 2.2$ & NS \\
\hline LV mass [g] & $234.4 \pm 51.1$ & $345.0 \pm 126.8$ & $P<0.0001$ & $293.2 \pm 72.5$ & $326.8 \pm 117.5$ & $310.1 \pm 96.0$ & $403.5 \pm 148.7^{3,5,10}$ & $P<0.0001$ \\
\hline LV hypertrophy [\%] & $95.2(\%)$ & $94.2 \%$ & NS & $92.3 \%$ & $96.6 \%$ & $90.0 \%$ & $95.6 \%$ & NS \\
\hline LV sys [mm] & $37.1 \pm 4.1$ & $40.7 \pm 7.6$ & $P=0.045$ & $38.5 \pm 5.7$ & $39.9 \pm 5.7$ & $38.7 \pm 6.3$ & $43.2 \pm 9.5^{1}$ & $P=0.035$ \\
\hline LV dias [mm] & $44.1 \pm 7.0$ & $48.7 \pm 7.2$ & $P=0.007$ & $46.0 \pm 5.0$ & $47.4 \pm 6.4$ & $47.7 \pm 5.7$ & $51.5 \pm 8.5^{2}$ & $P=0.003$ \\
\hline LA [mm] & $40.6 \pm 2.9$ & $42.4 \pm 4.1$ & $P=0.036$ & $41.3 \pm 2.9$ & $41.2 \pm 3.9$ & $41.7 \pm 3.2$ & $44.2 \pm 4.6^{2,4,8}$ & $P<0.0001$ \\
\hline $\mathrm{RV}[\mathrm{mm}]$ & $26.0 \pm 3.3$ & $27.5 \pm 3.8$ & NS & $27.6 \pm 2.1$ & $26.8 \pm 4.7$ & $26.9 \pm 3.8$ & $28.1 \pm 3.8$ & NS \\
\hline$E / A$ & $0.87 \pm 0.27$ & $1.09 \pm 0.59$ & NS & $1.09 \pm 0.73$ & $0.80 \pm 0.17$ & $1.14 \pm 0.18^{7}$ & $1.21 \pm 0.66$ & $P=0.014$ \\
\hline$E / E^{\prime}$ & $7.9 \pm 1.7$ & $10.7 \pm 4.8$ & NS & $8.6 \pm 4.2$ & $8.8 \pm 4.1$ & $12.6 \pm 4.6$ & $12.3 \pm 4.9$ & NS \\
\hline Dec (DT) & $209.6 \pm 56.2$ & $270.6 \pm 123.6$ & NS & $301.5 \pm 157.9$ & $321.3 \pm 132.8$ & $213.2 \pm 73.4$ & $246.6 \pm 98.2$ & NS \\
\hline Contractility disorders [\%] & $52.4 \%$ & $62.2 \%$ & NS & $36.8 \%$ & $45.0 \%$ & $43.8 \%$ & $88.4 \% \%^{2,6,9,11}$ & $P=0.0001$ \\
\hline $\mathrm{EF} \%$ & $53.0 \pm 3.5$ & $48.5 \pm 8.6$ & $P=0.012$ & $50.8 \pm 4.5$ & $51.1 \pm 8.4$ & $49.9 \pm 10.2$ & $45.5 \pm 8.9^{7}$ & $P=0.001$ \\
\hline Mitral valve fibrosis [\%] & $63.6 \%$ & $82.4 \%$ & NS $(P=0.079)$ & $87.0 \%$ & $73.9 \%$ & $70.6 \%$ & $88.9 \%$ & NS \\
\hline Aortic valve fibrosis [\%] & $13.6 \%$ & $12.0 \%$ & NS & $8.7 \%$ & $8.7 \%$ & $11.8 \%$ & $15.6 \%$ & NS \\
\hline Mitral valve calcification [\%] & $9.1 \%$ & $21.3 \%$ & NS & $8.7 \%$ & $13.0 \%$ & $11.8 \%$ & $15.6 \%$ & NS \\
\hline Aortic valve calcification [\%] & $9.5 \%$ & $39.8 \%$ & $P=0.008$ & $26.1 \%$ & $21.7 \%$ & $23.5 \%$ & $35.6 \%$ & NS \\
\hline IM [\%] & $63.6 \%$ & $71.6 \%$ & NS & $65.2 \%$ & $54.2 \%$ & $64.7 \%$ & $86.7 \%^{2}$ & $P=0.045$ \\
\hline IA [\%] & $4.8 \%$ & $12.8 \%$ & NS & $13.0 \%$ & $8.3 \%$ & $5.9 \%$ & $17.8 \%$ & NS \\
\hline IT [\%] & $36.4 \%$ & $58.3 \%$ & NS $(P=0.059)$ & $47.8 \%$ & $43.5 \%$ & $47.1 \%$ & $75.6 \%^{2,4,7}$ & $P=0.012$ \\
\hline Fetuin A [ng/ml] & $37.5(31.6-126.6)$ & $33.2(27.5-89.4)$ & $P=0.018$ & $70.6(30.9-119.7)$ & $34.1(28.5-92.5)$ & $31.4(26.2-114.0)$ & $29.8(25.5-37.5)^{2,4}$ & $P=0.002$ \\
\hline \multirow[t]{2}{*}{ Osteocalcin [ng/ml] } & $9.1 \pm 6.0$ & $13.6 \pm 10.3$ & $P=0.05$ & $10.6 \pm 9.0$ & $8.4 \pm 5.8$ & $11.7 \pm 9.8$ & $19.2 \pm 11.1^{3,4,9}$ & $P<0.0001$ \\
\hline & $8.2(5.1-13.0)$ & $10.5(5.0-23.1)$ & & $6.7(4.3-19.1)$ & $7.6(4.3-11.9)$ & $9.2(4.5-17.9)$ & $22.9(8.5-28.2)$ & \\
\hline Osteopontin [ng/ml] & $8.8(7.2-37.8)$ & $9.3(7.8-17.8)$ & NS & $9.4(6.7-20.9)$ & $8.1(7.4-16.1)$ & $9.8(8.1-25.2)$ & $9.3(8.0-13.8)$ & NS \\
\hline \multirow[t]{2}{*}{ Osteoprotegerin [pmol/l] } & $7.6 \pm 5.5$ & $8.5 \pm 6.2$ & NS & $7.5 \pm 6.9$ & $5.8 \pm 4.6$ & $8.2 \pm 6.0$ & $10.8 \pm 6.2^{2}$ & $P=0.005$ \\
\hline & $5.7(2.9-12.0)$ & $7.4(3.5-12.2)$ & & $7.2(1.1-11.0)$ & $5.2(1.1-9.5)$ & $6.3(3.7-11.6)$ & $10.1(6.1-14.4)$ & \\
\hline MGP $[\mathrm{ng} / \mathrm{ml}]$ & $92.9 \pm 28.5$ & $86.7 \pm 36.7$ & NS & $77.1 \pm 43.5$ & $83.1 \pm 33.9$ & $89.5 \pm 32.1$ & $92.6 \pm 36.7$ & NS \\
\hline ABCG1 [ng/ml] & $2.25(0.98-2.58)$ & $1.93(0.72-2.43)$ & NS & $1.94(1.64-2.34)$ & $1.86(0.59-2.36)$ & $2.19(0.89-2.63)$ & $1.84(0.46-2.49)$ & NS \\
\hline ABCA1 $[\mathrm{ng} / \mathrm{ml}]$ & $0.70(0.62-0.75)$ & $0.60(0.44-0.74)$ & NS $(P=0.079)$ & $0.71(0.55-0.88)$ & $0.51(0.41-0.71)$ & $0.59(0.42-1.02)$ & $0.58(0.30-0.71)$ & NS $(P=0.054)$ \\
\hline \multirow[t]{2}{*}{ MMP-2 [ng/ml] } & $94.8(54.2-166.3)$ & $129.9(73.4-219.3)$ & $P=0.045$ & $206.9 \pm 142.7$ & $202.5 \pm 152.3$ & $160.6 \pm 130.0$ & $130.7 \pm 105.8$ & $P=0.008$ \\
\hline & $113.1 \pm 75.0$ & $166.0 \pm 129.9$ & & $166.9(86.4-304.5)^{1}$ & $156.1(105.7-274.2)^{1}$ & $136.5(70.6-225.1)$ & $103.4(63.4-160.1)$ & \\
\hline MMP-9 [ng/ml] & $21.5 \pm 6.4$ & $22.5 \pm 7.1$ & NS & $20.1 \pm 7.4$ & $21.9 \pm 6.2$ & $22.7 \pm 8.0$ & $23.9 \pm 6.9$ & NS \\
\hline TIMP-1 [ng/ml] & $21.8 \pm 3.7$ & $21.4 \pm 2.4$ & NS & $19.8 \pm 3.5$ & $21.8 \pm 2.2$ & $21.7 \pm 1.9$ & $21.9 \pm 1.5^{4}$ & $P=0.048$ \\
\hline
\end{tabular}


Table 1 Detailed characteristics of included patients (Continued)

TIMP-2 [ng/ml]

$25.4 \pm 7.0$

$6.1(3.0-11.4)$

MMP-2/TIMP-2

MMP-9/TIMP-1

$4.5(2.5-7.9)$

$1.09(0.65-1.28)$

Renalase $[\mathrm{ng} / \mathrm{ml}]$

$251.0 \pm 157.0$

$1.15(0.75-1.37)$

$316.1 \pm 155.3$

vs control, $p<0.05 ;^{2}$ vs control, $p<0.01 ;{ }^{3}$ vs control, $p<0.001$.

${ }^{4}$ vs stage $\mathrm{I}-\mathrm{II}, \mathrm{p}<0.05 ;{ }^{5}$ vs stage $\mathrm{I}-\mathrm{II}, \mathrm{p}<0.01 ;{ }^{6}$ vs stage $\mathrm{I}-\mathrm{II}, \mathrm{P}<0.001$

${ }^{7}$ vs stage III, $p<0.05 ;{ }^{8}$ vs stage III, $p<0.01 ;{ }^{9}$ vs stage III, $p<0.001$.

${ }^{10}$ vs stage IV, $\mathrm{p}<0.05 ;{ }^{11}$ vs stage IV, $\mathrm{p}<0.001$.

\section{$\mathrm{P}=0.005$}

NS $(P=0.056)$

NS

$P=0.026$
$23.5 \pm 6.4$

$11.0(5.7-17.9)^{2}$

$1.16 \pm 0.56$

$354.5 \pm 181.6$
$23.9 \pm 5.5$

$7.4(4.4-14.7)$

$1.17 \pm 0.71$

$235.3 \pm 152.3$
$25.3 \pm 6.5$

$6.3(3.3-11.4)$

$1.08 \pm 0.41$

$279.4 \pm 162.2$
$27.3 \pm 8.0^{2}$

$3.8(2.0-8.4)^{5}$

$1.11 \pm 0.37$

$369.0 \pm 110.5^{2,5}$
$P=0.003$

$P=0.001$

NS

$P<0.0001$ 
Table 2 Correlation between the presence of fibrosis and calcification and selected parameters

\begin{tabular}{lllll}
\hline & Sex $($ male $)$ & Age & Ca $^{2+}$ & Inorganic phosphate \\
\hline Mitral valve fibrosis & $1.39(0.36-5.28) \mathrm{NS}$ & $1.15(1.07-1.24) \mathrm{P}<0.0001$ & $0.98(0.06-16.94) \mathrm{NS}$ & $3.1(0.56-17.19) \mathrm{NS}$ \\
Aortic valve fibrosis & $0.33(0.09-1.22) \mathrm{NS}$ & $1.02(0.97-1.08) \mathrm{P}<0.0001$ & $0.53(0.04-7.51) \mathrm{NS}$ & $1.13(0.36-3.47) \mathrm{NS}$ \\
Mitral valve calcification & $1.64(0.59-4.51) \mathrm{NS}$ & $1.05(1.00-1.09) \mathrm{P}=0.037$ & $0.25(0.02-2.41) \mathrm{NS}$ & $0.84(0.30-2.34) \mathrm{NS}$ \\
Aortic valve calcification & $1.61(0.65-3.97) \mathrm{NS}$ & $1.04(1.00-1.08) \mathrm{P}=0.054$ & $0.86(0.11-6.82) \mathrm{NS}$ & $4.37(1.57-12.15) \mathrm{P}=0.005$ \\
\hline
\end{tabular}

ABCA1 and ABCG1 and HDL cholesterol, LDL, total cholesterol and triglycerides levels. There was also no relationship between the level of these proteins and a marker of inflammation (CRP) or a marker of renal injury (creatinine). A weak association was observed between the concentration of metalloproteinase- 9 and the level of CRP $(\mathrm{p}=0.066)$ and a stronger one between TIMP-2 and MDRD-GFR $(p=0.007)$. The concentration of TIMP-2 also correlated with the level of iron $(\mathrm{p}=0.018)$. In this study, a relationship between the concentration of renalase and the kidney injury markers creatinine and urea was noted.

Statistically significant results of the correlation analysis are presented in Table 3.

\section{Discussion}

Biochemical and physiological abnormalities in chronic kidney disease are associated with the attempts of the human body to maintain homeostasis despite progressive loss of nephrons and impaired kidney function. Multiple adaptive and maladaptive processes occurring at that time affect mainly the cardiovascular, neurological, haematological, musculoskeletal, and immunological systems $[13,14]$.

This preliminary study analysed the possible markers of increased cardiovascular risk and calcification processes occurring in CKD patients.

The results of analysis of biochemical parameters significantly higher levels of $\mathrm{K}^{+}$, lower haemoglobin and iron, as well as higher levels of CRP, inorganic P and triglycerides in patients with CKD stages I-V in comparison with the control group - are consistent with the results of other studies $[15,16]$ and are related to kidney damage. Decreased levels of haemoglobin are not surprising since CKD patients frequently suffer from anaemia. The main factors leading to the development of anaemia in this group of patients are blood loss, shortened red cell life span, vitamin deficiency, the 'uremic milieu', iron and erythropoietin (EPO) deficiency as well as reduced ability to bind $\mathrm{Fe}$, inflammation and hyperparathyroidism [13]. The presence of the inflammatory state in CKD patients is confirmed by high CRP levels. Significantly higher concentrations of urea, creatinine and uric acid in patients with CKD stages I-V are not astonishing, since these are well-known markers of kidney damage. In CKD patients iron homeostasis is altered.
The level of transferrin is decreased, which negatively affects the capacity of the iron-transporting system, and the release of iron stored in macrophages and hepatocytes is complicated [13,17]. It is believed that lipid abnormalities are a common phenomenon in patients with kidney disease. In the early stages of kidney disease the lipid profile may remain in the normal range, but with the progression of CKD hypertriglyceridaemia, elevated concentrations of total cholesterol, VLDL (very low density lipoprotein), IDL (intermediate density lipoprotein), LDL and decreased HDL cholesterol appear [18]. In this study significantly lower concentrations of total cholesterol and LDL cholesterol in CKD patients compared to healthy volunteers were observed. Triglyceride concentrations are usually high in CKD patients and this disturbance is seen in early stages of CKD and is present in up to $70 \%$ of ESRD patients $[18,19]$. Highdensity lipoprotein (HDL) cholesterol is subnormal in the majority of patients, which is consistent with the results of this study. Uraemia causes qualitative changes in the composition of LDL, increases the number of small, dense LDL particles and facilitates their oxidation and glycation. LDL cholesterol in CKD may be normal or lower; however, the proportion of small dense LDL particles, which are considered to be highly atherogenic, is increased [20]. According to studies [18], the profile of dyslipidaemia is similar to that found in patients with accelerated atherosclerosis. It seems that greater severity of atherosclerosis in patients with CKD may also be associated with disorders of calcium-phosphate metabolism. Impaired excretion of phosphate leads to its increased concentration, to binding with calcium in tissues and to the accumulation of such compound in the arteries, which increases the risk of heart attack and stroke [21]. High levels of phosphate usually appear when the GFR falls below $60 \mathrm{ml} / \mathrm{min}$ and worsens with the deterioration of renal excretory functions. Hyperphosphataemia stimulates parathyroid glands to increased secretion of parathyroid hormone (PTH), which in turn increases the release of phosphate from the bone, contributing to further accumulation of phosphate in serum. High levels of inorganic phosphate in CKD patients observed in this study are in accordance with the results of other studies.

Progressive left ventricular enlargement seems to be the most characteristic morphological pattern of dialysis 
Table 3 Results of analysis of correlation between concentration of selected proteins and biochemical parameters

\begin{tabular}{|c|c|c|c|c|c|c|c|c|c|c|c|c|c|}
\hline & $\mathrm{Ca}^{2+}$ & Inorganic $P$ & CRP & & HDL & LDL & TCH & TG & CRP & GFR-MDRD & $\mathrm{Ca}^{2+}$ & Inorganic $\mathrm{P}$ & $\mathrm{Fe}$ \\
\hline Osteopontin & $0.024 \mathrm{NS}$ & $0.009 \mathrm{NS}$ & 0.094 NS & $\mathrm{ABCA1}$ & $0.012 \mathrm{NS}$ & 0.016 NS & $0.127 \mathrm{NS}$ & $0.032 \mathrm{NS}$ & $-0.154 \mathrm{NS}$ & & & & \\
\hline Osteoprotegerin & -0.117 NS & $0.385 P<0.0001$ & $0.290 P=0.001$ & $\mathrm{ABCG} 1$ & $0.150 \mathrm{NS}$ & -0.109 NS & 0.052 NS & -0.097 NS & -0.014 NS & & & & \\
\hline Osteokalcin & -0.144 NS & $0.192 \mathrm{P}=0.041$ & 0.019 NS & MMP-2 & -0.079 NS & -0.001 NS & 0.096 NS & $0.125 \mathrm{NS}$ & $0.113 \mathrm{NS}$ & 0.048 NS & 0.095 NS & -0.119 NS & 0.149 NS \\
\hline Fetuin A & $0.270 P=0.003$ & $-0.296 P=0.001$ & -0.117 NS & MMP-9 & $-0.075 \mathrm{NS}$ & -0.060 NS & -0.104 NS & -0.040 NS & $0.167 \mathrm{NS}(p=0.066)$ & -0.162 NS & -0.038 NS & 0.026 NS & -0.067 NS \\
\hline \multirow[t]{2}{*}{ MGP } & $-0.41 \mathrm{NS}$ & -0.005 NS & 0.034 NS & TIMP-1 & $-0.062 \mathrm{NS}$ & $0.084 \mathrm{NS}$ & -0.067 NS & -0.093 NS & 0.007 NS & -0.169 NS & -0.083 NS & 0.105 NS & -0.095 NS \\
\hline & Creatinine & Urea & CRP & TIMP-2 & -0.019 NS & 0.029 NS & 0.050 NS & $0.128 \mathrm{NS}$ & -0.028 NS & $-0.272 P=0.007$ & $-0.091 \mathrm{NS}$ & $0.061 \mathrm{NS}$ & $-0.223 P=0.018$ \\
\hline \multirow[t]{2}{*}{ Renalase } & 0.410 & 0.376 & 0.073 NS & & & & & & & & & & \\
\hline & $P<0.0001$ & $P<0.0001$ & & & & & & & & & & & \\
\hline
\end{tabular}


patients and is one of the key prognostic factors for cardiovascular mortality rates in ESRD patients [22,23]. In this study systolic and diastolic dimensions of the left ventricle as well as LV mass differed significantly between CKD patients and controls. These parameters were much higher in ESRD patients than in patients with CKD stage I/II According to Zoccali et al. [24], patients in the highest tertiles of change in LV mass undergoing haemodialysis had a 50\% mortality risk and $>85 \%$ $\mathrm{CV}$ event risk at 3 years. Moreover, another study [25] demonstrated that a $10 \%$ decrease in left ventricle (LV) mass ( 29 g) was associated in haemodialysis patients with a $28 \%$ decrease in mortality risk from cardiovascular causes over an almost 5-year follow-up. Numerous studies have demonstrated that diastolic dysfunction, which is common in chronic kidney disease (CKD), accounts for $40 \%-66 \%$ of cardiovascular complications [26]. The proper diagnosis of LV diastolic dysfunction is very important since it has been demonstrated that it provides independent, prognostic value for long-term mortality and cardiovascular death in patients with endstage renal disease [27]. Also the study of Iwabuchi et al. [28] demonstrated that E/E' ratio is a significant predictor of cardiovascular events in haemodialysis patients with preserved LV systolic function and is better than other echocardiographic parameters. However, in this study significant differences in indices of diastolic dysfunction (E/A and E/E') between study group and controls were not observed. This may be due to the fact that the studied groups were not large.

Lower ejection fraction and frequent mitral and tricuspid regurgitation observed in CKD patients in this study is consistent with the results of other studies [29]. It has been observed that the calcification process is common and more severe in the CKD population compared with healthy people [30]. According to studies, in addition to arterial wall calcification in patients with CKD valvular calcification is frequently observed. These changes are localized mainly within the mitral valve ring and extend towards valve leaflets [31,32]. It is believed that the severity of vascular and valvular calcification in patients undergoing haemodialysis correlates with the incidence of cardiovascular complications and is a predictor of cardiovascular mortality [31,33]. In this study aortic and mitral valve calcification was observed, and they were much more frequent in CKD patients than in healthy volunteers. In the study of Leskinen et al. [34] combined prevalence of mitral or aortic valve calcification was $31 \%$ in pre-dialysis patients, $50 \%$ in dialysis patients and $12 \%$ in controls $(\mathrm{p}=0.001)$. In the Multi-Ethnic Study of Atherosclerosis in patients with moderate CKD and no clinical cardiovascular disease, calcification of the aortic valve and mitral valve was present in 25 and $20 \%$ of people respectively [35]. It is believed that the severity of vascular and valvular calcification in haemodialysis patients correlates with the incidence of cardiovascular complications and is a predictor of cardiovascular mortality [32,36]. The contribution of traditional risk factors does not fully explain the high frequency of cardiovascular disease, and thus scientists look for new mechanisms involved in its pathogenesis [37-42]. The coronary artery calcification score (CACS) may be as much as 5-fold higher in patients on maintenance haemodialysis than in age-matched nonCKD patients [43]. Nowadays it seems that the differentiation of vascular smooth muscle cells (VSMCs) into chondrocytes or osteoblast-like cells is a key element in vascular/valvular pathogenesis [44]. Many bone-associated proteins, including osteocalcin (OC), matrix $\gamma$-carboxyglutamic acid protein (MGP), osteoprotegerin (OPG), osteopontin (OPN) and fetuin A, are expressed in atherosclerotic plaques and participate in atherosclerotic calcification. In an in vitro study, exogenous osteocalcin inhibited the process of calcification [45]. According to the literature, its concentration in patients with CKD is high. Increased serum concentration of osteocalcin in patients with CKD may be associated with reduced renal clearance, increased bone metabolism or a combination of both phenomena $[46,47]$. In this study, only concentrations of fetuin A (associated with the presence of massive calcifications of soft tissue and widespread arterial calcification $[48,49])$ and osteocalcin (which is considered to be the key factor in the development of atherosclerosis) significantly differed between patients with chronic kidney disease and controls. The concentration of osteocalcin was lowest in patients with stage I/II CKD and gradually increased to reach its highest value in patients with stage $\mathrm{V} /$ dialysis. According to Delmas et al. [47], raised levels of circulating osteocalcin in patients with mild or moderate renal impairment reflect enhanced bone metabolism rather than decreased renal filtration. In this study, fetuin A level decreased significantly with the progression of CKD, which is consistent with the results of other studies [50,51]. Schafer et al. [52] suggested that fetuin A deficiency in haemodialysis patients may be responsible for the development of calciphylaxis, which includes changes in small arterioles. A low level of fetuin $\mathrm{A}$ in these patients is considered an independent risk factor for increased mortality from cardiovascular causes [53]. Furthermore, Wang et al. [54] demonstrated that serum concentration of fetuin A decreased as MIA syndrome intensified. However, our study failed to observe such an association, probably due to the quite small study group. Also, osteoprotegerin deficiency leads to vascular calcification since it inhibits osteoclast differentiation and is a crucial modulator of bone resorption $[37,55]$. In this study, the concentration of osteoprotegerin in controls and study groups did not differ significantly; however, the authors observed its lowest values in subjects with I/II stage CKD and highest in 
patients with stage V/dialysis. The results showing an increase of osteoprotegerin levels with increasing renal impairment are consistent with the results of other studies. The study by Amann K [56] showed that levels of osteoprotegerin in CKD patients are elevated, which is a defence mechanism against vascular calcification. Bucay et al. [48] demonstrated that mice lacking the osteoprotegerin gene had severe osteoporosis accompanied by rapid progression of calcification of arteries, while the exogenous administration of OPG inhibited the vascular calcification process. On the other hand, it was found that the expression of OPG in the atheromatous plaque and in vascular smooth muscle cells is very high and it is regulated by a number of inflammatory cytokines [57]. Other studies have shown that both the process of vascular calcification [58] and the aortic calcification index [59] correlated with serum concentration of OPG in patients on haemodialysis. It seems that increased levels of OPG in patients with CKD can affect both the presence of systemic inflammation and local dysfunction of vascular endothelium [60]. In this study, there are slight differences in osteopontin concentration between groups, however, they did not reach statistical significance level, probably due to small study groups.

Because the calcification process is in part associated with the degradation of elastin, this study examined the level of metalloproteinases (MMPs) and their inhibitors. Degradation of elastin by matrix metalloproteinases (MMP-2 and -9) [37,61,62] activates the mitogenactivated protein kinase (MAPK) signalling pathway and may further result in the induction of Cbfa1/Runx2 and sequentially initiate the transformation of VSMCs into osteoblast-like cells $[37,63]$. Analysis of results of this study revealed significantly higher levels of MMP-2 in patients with chronic kidney disease in comparison to the control group. Also the study of Musial et al. [33] demonstrated that concentrations of MMP-2 increased with the decline of renal function. Similarly, Nagano et al. [64] observed a correlation between serum concentration of MMP-2 and kidney function parameters and confirmed that MMP-2 can be an indicator of the severity of atherosclerosis in CKD patients. Apart from MMP-2, the role of MMP-9 in the pathogenesis of vascular changes in atherosclerosis has also been established. The study by Chen et al. [65] revealed increased expression of MMP-2 and MMP-9 in areas of aorta calcification. Moreover, MMP inhibitors decreased calcification of aorta rings from normal and CKD rats, which may suggest that degradation of the extracellular matrix is a critical step in the pathogenesis of arterial calcification in CKD [65]. In this study, significant differences in concentration of TIMP-2 between CKD patients and controls and in metalloproteinase inhibitors TIMP-1 and TIMP-2 and the MMP-2/TIMP-2 ratio between $\mathrm{CKD}$ subjects in various stages were observed. The study of Musial et al. [33] demonstrated that concentrations of TIMP- 1 and -2 start to increase in the advanced stages of CKD, so they are probably a response to the increased activity of matrix metalloproteinases.

A key stage in the atherosclerotic process is the formation of foam cells from macrophages. Numerous studies indicate that combined action of transport proteins ABCA1 and ABCG1 in macrophages are very important for the anti-atherogenic effect of HDL. ABCA1 plays an important role in reverse cholesterol transport; its activity is associated with HDL cholesterol concentration and atherosclerosis. ABCG1 enables transport of phospholipids and cholesterol from cell membranes to ApoAI-rich HDL precursors and can act synergistically with ABCA1 to remove cholesterol from cells [66]. Both transporters mediate macrophage cholesterol efflux, and protect against the formation of foam cells from macrophages, infiltration of inflammatory cells, apoptosis and atherosclerosis [67]. In humans, a homozygous variant of ABCA1 present in Tangier disease is associated with a very low level of HDL cholesterol, a high concentration of triglycerides, and six times higher risk of cardiovascular disease [68]. In turn, the disruption of the ABCG1 gene in mice fed with a high-fat diet results in a massive accumulation of lipid in macrophages in various tissues [69]. However, no significant differences in ABCA1 and ABCG1 between study and control groups were found. Increased levels of renalase in CKD patients, observed in this study, are consistent with the study of Desir et al. [70,71]. Concentration of this protein was higher in patients with early stages of CKD than in the control group. Similar observations were made in the Malyszko et al. [72,73] study, in which the renalase level was much higher in patients who had undergone renal transplant than in healthy subjects. Renalase concentration in patients with CKD correlates with increased plasma norepinephrine levels, systolic blood pressure and proteinuria, suggesting that this protein plays an important role in the metabolism of catecholamines, participates in the development of hypertension and cardiovascular disorders, and may directly or indirectly contribute to kidney damage [74] and increased mortality of CKD patients [75,76].

Our study also revealed a correlation between osteocalcin level and inorganic $\mathrm{P}$ and between osteoprotegerin and inorganic $\mathrm{P}$ and CRP. In patients with CKD, it is well established that hyperphosphataemia is associated with the development of vascular calcification [38,44,77-82]. Recent studies have demonstrated that high extracellular phosphate levels induce the transformation of VSMCs into osteoblast-like cells, which suggests that vascular calcification is an active process. Moreover, elevated extracellular phosphate levels are associated with the increase in bone-associated proteins such as osteocalcin and osteopontin [38,78]. Fetuin A correlated well with the level of 
calcium ions. Also in the study by Cagli et al. there was a positive correlation between serum fetuin $\mathrm{A}$ and calcium [80]. In this study, a relationship between the concentration of renalase and the kidney injury markers creatinine and urea was noted. In the study by Malyszko et al. [72], renalase levels in patients after kidney transplantation also correlated with plasma creatinine concentration and MDRD eGFR values.

\section{Limitations}

Our study has some limitations. The number of participants included to the study is relatively small (139 patients with CKD and 45 healthy volunteers). Study and control groups differ in age due to the fact that it is difficult to find healthy people aged $60-70$ years to match study group. There are also differences in other demographic data such as sex, diabetes mellitus and hypertension between groups.

\section{Conclusions}

In conclusion, we showed that significantly decreased levels of fetuin A and increased concentration of osteocalcin were present in all patients with chronic kidney disease. Moreover, MMP-2 and TIMP-2 concentrations were much higher in patients with chronic kidney disease, suggesting that these factors may be involved in the pathogenesis of CAD in patients with CKD. Lack of significant differences in parameters associated with the transport of cholesterol may mean that commonly measured cholesterol level does not play the important role in the CV risk stratification in CKD patients. Moreover, according to literature, in uremic conditions HDL particles may lose their protective properties and also become atherogenic. The level of renalase was significantly higher in patients with CKD than in controls and it increased with the deterioration of renal function. The results suggest that that valvular calcifications may constitute a marker for atherosclerosis.

\section{Competing interest}

The authors declare that they have no competing interests.

\section{Authors' contribution}

AG-B - planned the study protocol, took part in the acquisition of data and coordinate the research, took part in the data analysis and drafted the manuscript; MM-K - took part in the acquisition of data; BF-S - took part in the acquisition of data; $\mathrm{MN}$ - took part in the statistical data analysis; $\mathrm{MB}$ - conceived of the study, participated in its coordination, revised it critically and prepared the final version of the manuscript; JR - conceived of the study, participated in its coordination, revised it critically and prepared the final version of the manuscript. All authors read and approved the final manuscript.

\section{Acknowledgment}

This work was funded by luventus Plus 2012 grant no. IP2011014571 from the Polish Ministry of Science and Higher Education.

\section{Author details}

'Department of Nephrology, Hypertension and Family Medicine, WAM University Hospital of Lodz, Medical University of Lodz, Zeromskiego 113, 90-549 Lodz, Poland. 'Department of Hypertension, Medical University of Lodz, Lodz, Poland. ${ }^{3}$ Nofer Institute of Occupational Medicine, Lodz, Poland.

Received: 15 July 2014 Accepted: 25 July 2014

Published: 21 August 2014

\section{References}

1. Singaraja RR, Fievet C, Castro G, James ER, Hennuyer N, Clee SM, Bissada N, Choy JC, Fruchart JC, McManus BM, Staels B, Hayden MR: Increased ABCA1 activity protects against atherosclerosis. J Clin Invest 2002, 110:35-42

2. Sarnak MJ, Levey AS, Schoolwerth AC, Coresh J, Culleton B, Hamm LL, McCullough PA, Kasiske BL, Kelepouris E, Klag MJ, Parfrey P, Pfeffer M, Raij L, Spinosa DJ, Wilson PW: American heart association councils on kidney in cardiovascular disease, high blood pressure research, clinical cardiology, and epidemiology and prevention. Kidney disease as a risk factor for development of cardiovascular disease. A statement from the American heart association councils on kidney in cardiovascular disease, high blood pressure research, clinical cardiology, and epidemiology and prevention. Circulation 2003, 108:2154-2169.

3. Foley RN, Parfrey PS, Sarnak MJ: Clinical epidemiology of cardiovascular disease in chronic renal disease. Am J Kidney Dis 1998, 32:S112-S119.

4. Go AS, Mozaffarian D, Roger VL, Benjamin EJ, Berry JD, Blaha MJ, Dai S, Ford ES, Fox CS, Franco S, Fullerton HJ, Gillespie C, Hailpern SM, Heit JA, Howard VJ, Huffman MD, Judd SE, Kissela BM, Kittner SJ, Lackland DT, Lichtman JH, Lisabeth LD, Mackey RH, Magid DJ, Marcus GM, Marelli A, Matchar DB, McGuire DK, Mohler ER 3rd, Moy CS, et al: AHA statistical update heart disease and stroke statistics - 2014 update. A report from the american heart association. Circulation 2014, 129:e28-e292.

5. US Renal Data System: 2002 Annual Data Report, The National Institutes of Health, National Institute of Diabetes and Digestive and Kidney Diseases, Bethesda, MD. 2002.

6. Foley RN, Parfrey PS, Harnett JD: Clinical and echocardiographic disease in patients starting end-stage renal disease therapy. Kidney Int 1995 47:186-192.

7. Saha M, Faroque MO, Alam KS, Alam MM, Ahmed S: Chronic kidney disease specific cardiovascular risk factors among non dialytic patients with chronic kidney disease stage- $\mathrm{V}$-An experience of a specialized hospital Bangladesh. Med Res Counc Bull 2012, 38:18-22.

8. Rocco MV, Yan G, Gassman J, Lewis JB, Ornt D, Weiss B, Levey AS: Hemodialysis Study Group, The National Institutes of Health-funded Hemodialysis. Health Care Financing Administration: Comparison of causes of death using HEMO Study and HCFA end-stage renal disease death notification classification systems. Am J Kidney Dis 2002 39:146-153.

9. Locatelli F, Marcelli D, Conte F, D'Amico M, Del Vecchio L, Limido A Malberti F, Spotti D: Registro Lombardo Dialisi e Trapianto: cardiovascular disease in chronic renal failure: the challenge continues. Nephrol Dial Transplant 2000, 15(Suppl 5):69-80.

10. Culleton BF, Larson MG, Wilson PW, Evans JC, Parfrey PS, Levy D: Cardiovascular disease and mortality in a community based cohort with mild renal insufficiency. Kidney Int 1999, 56:2214-2219.

11. Duymelinck C1, Deng JT, Dauwe SE, De Broe ME, Verpooten GA: Inhibition of the matrix metalloproteinase system in a rat model of chronic cyclosporine nephropathy. Kidney Int 1998, 54:804.

12. Jain S, Bicknell GR, Nicholson ML: Molecular changes in extracellular matrix turnover after renal ischaemia-reperfusion injury. Br J Surg 2000, 87:1188.

13. Nurko S: Anemia in chronic kidney disease: causes, diagnosis, treatment. Cleve Clin J Med 2006, 73(3):289-297.

14. Gluba A, Banach M, Hannam S, Mikhailidis DP, Sakowicz A, Rysz J: The role of Toll-like receptors in renal diseases. Nat Rev Nephrol 2010, 6(4):224-235.

15. Martínez-Castelao A1, Górriz JL, Portolés JM, De Alvaro F, Cases A, Luño J, Navarro-González JF, Montes R, De la Cruz-Troca JJ, Natarajan A, Batlle D: Baseline characteristics of patients with chronic kidney disease stage 3 and stage 4 in Spain: the MERENA observational cohort study. BMC Nephrol 2011, 12:53. 
16. Mahon A, Jenkins K (Eds): Chronic Kidney Disease, Stages 1-3. A guide to Clinical Practice. 1st edition. Luzern, Switzerland: EDTNA/ERCA; 2007.

17. Besarab A, Frinak S, Yee J: An indistinct balance: the safety and efficacy of parenteral iron therapy. J Am Soc Nephrol 1999, 10:2029-2043.

18. Piecha G, Adamczak M, Ritz M: Dyslipidemia in chronic kidney disease. Pathogenesis and intervention. Pol Arch Med Wewn 2009, 119(7-8):487-492.

19. Nikolic D, Banach M, Nikfar S, Salari P, Mikhailidis DP, Toth PP, Abdollahi M, Ray KK, Pencina MJ, Malyszko J, Rysz J, Rizzo M: Lipid and blood pressure meta-analysis collaboration group: a meta-analysis of the role of statins on renal outcomes in patients with chronic kidney disease. Is the duration of therapy important? Int J Cardiol 2013, 168(6):5437-5447.

20. Nikolic D, Nikfar S, Salari P, Rizzo M, Ray KK, Pencina MJ, Mikhailidis DP, Toth PP, Nicholls SJ, Rysz J, Abdollahi M, Banach M: Lipid and blood pressure meta-analysis collaboration group: effects of statins on lipid profile in chronic kidney disease patients: a meta-analysis of randomized controlled trials. Curr Med Res Opin 2013, 29(5):435-451.

21. Roberts DM, Singer RF: Management of renal bone disease. Aust Prescr 2010, 33:34-37.

22. Foley RN, Parfrey PS, Harnett JD, Kent GM, Murray DC, Barre PE: The long-term evolution of uremic cardiomyopathy. Kidney Int 1998, 54:1720-1725

23. Middleton RJ, Parfrey PS, Foley RN: Left ventricular hypertrophy in the renal patient. JASN 2001, 12(5):1079-1084.

24. Zoccali C, Benedetto FA, Mallamaci F, Tripepi G, Giacone G, Stancanelli B, Cataliotti A, Malatino LS: Left ventricular mass monitoring in the follow-up of dialysis patients: prognostic value of left ventricular hypertrophy progression. Kidney Int 2004, 65:1492-1498.

25. London GM1, Pannier B, Guerin AP, Blacher J, Marchais SJ, Darne B, Metivier F, Adda H, Safar ME: Alterations of left ventricular hypertrophy in and survival of patients receiving hemodialysis: follow-up of an interventional study. J Am Soc Nephrol 2001, 12:2759-2767

26. Arodiwe EB, Ulasi II, ljoma CK, Ike SO: Left ventricular diastolic function in a predialysis patient population. West Afr J Med 2010, 29(4):225-229.

27. Wang AYM, Wang M, Lam CWK, Chan IHS, Zhang Y, Sanderson JE: Left ventricular filling pressure by Doppler echocardiography in patients with end-stage renal disease. Hypertension 2008, 52(1):107-114.

28. Iwabuchi Y, Ogawa T, Inoue T, Otsuka K, Nitta K: Elevated E/E' predicts cardiovascular events in hemodialysis patients with preserved systolic function. Intern Med 2012, 51(2):155-160.

29. Zapolski T, Wysokinski A, Janicka L, Grzebalska A, Ksiazek A: Aortic stiffness and valvular calcifications in patients with end-stage renal disease. Pol Arch Med Wewn 2008, 118(3):111-118.

30. Kidney Disease: Improving Global Outcomes (KDIGO) CKD-MBD Work Group: KDIGO clinical practice guideline for the diagnosis, evaluation, prevention, and treatment of chronic kidney disease-mineral and bone disorder (CKD-MBD). Kidney Int 2009, 76(suppl 113):S1-S130.

31. Janicka L1, Czekajska-Chehab E, Duma D, Grzebalska AM, Mierzicki P, Orłowska-Kowalik G, Solski J, Drop A, Ksiazek A: The study of some risk factors of coronary artery calcification in patients on peritoneal dialysis. Pol Arch Med Wewn 2006, 4:14-20. in polish.

32. Relterowa M, Moe SM: Vascular calcification in dialysis patients: Pathogenesis and consequences. Am J Kidney Dis 2003, 41(3 Suppl 1):S96-S99.

33. Musial K, Zwolinska D: Matrix metalloproteinases (MMP-2,9) and their tissue inhibitors (TIMP-1,2) as novel markers of stress response and atherogenesis in children with chronic kidney disease (CKD) on conservative treatment. Cell Stress Chaperones 2011, 16(1):97-103.

34. Leskinen $Y$, Paana T, Saha H, Groundstroem K, Lehtimäki T, Kilpinen S, Huhtala $\mathrm{H}$, Airaksinen J: Valvular calcification and its relationship to atherosclerosis in chronic kidney disease. J Heart Valve Dis 2009, 18(4):429-438

35. Adeney KL, Siscovick DS, Ix JH, Seliger SL, Shlipak MG, Jenny NS, Kestenbaum BR: Association of serum phosphate with vascular and valvular calcification in moderate CKD. JASN 2009, 20(2):381-387.

36. Brenner BM: Remission of renal disease: recounting the challenge, acquiring the goal. J Clin Invest 2002, 110:1753-1758.

37. Mizobuchi M, Towler D, Slatopolsky E: Vascular calcification: the killer of patients with chronic kidney disease. J Am Soc Nephrol 2009, 20:1453-1464

38. London GM, Guerin AP, Marchais S, Metivier F, Pannier B, Adda H: Arterial media calcification in end-stage renal disease: Impact on all-cause and cardiovascular mortality. Nephrol Dial Transplant 2003, 18:1731-1740.

39. Blacher J, Guerin AP, Pannier B, Marchais SJ, London GM: Arterial calcifications, arterial stiffness, and cardiovascular risk in end-stage renal disease. Hypertension 2001, 38:938-942.

40. Wang AY, Wang M, Woo J, Lam CW, Li PK, Lui SF, Sanderson JE: Cardiac valve calcification as an important predictor for all-cause mortality and cardiovascular mortality in long-term peritoneal dialysis patients: a prospective study. J Am Soc Nephrol 2003, 14:159-168.

41. Olechnowicz-Tietz S, Gluba A, Paradowska A, Banach M, Rysz J: The risk of atherosclerosis in patients with chronic kidney disease. Int Urol Nephrol 2013, 45(6):1605-1612.

42. Gluba A, Mikhailidis DP, Lip GY, Hannam S, Rysz J, Banach M: Metabolic syndrome and renal disease. Int J Cardiol 2013, 5(164(2)):141-150.

43. Braun J, Oldendorf M, Moshage W, Heidler R, Zeitler E, Luft FC: Electron beam computed tomography in the evaluation of cardiac calcification in chronic dialysis patients. Am J Kid Dis 1996, 27(3):394-401.

44. Moe SM, Chen NX: Mechanisms of vascular calcification in chronic kidney disease. JASN 2008, 19(2):213-216.

45. Wada T1, McKee MD, Steitz S, Giachelli CM: Calcification of vascular smooth muscle cell cultures: inhibition by osteopontin. Circ Res 1999, 84:166-178.

46. Razzaque MS: Osteocalcin: a pivotal mediator or an innocent bystander in energy metabolism? Nephrol Dial Transplant 2011, 26(1):42-45.

47. Delmas PD, Wilson DM, Mann KG, Riggs BL: Effect of renal function on plasma levels of bone Gla-protein. J Clin Endocrinol Metab 1983, 57:1028-1030

48. Bucay N, Sarosi I, Dunstan CR, Morony S, Tarpley J, Capparelli C, Scully S, Tan HL, Xu W, Lacey DL, Boyle WJ, Simonet WS: Osteoprotegerin-deficient mice and onset osteoporosis and arterial calcification. Genes Dev 1998 $12: 1260-1268$

49. Jersmann HP, Dransfield I, Hart SP: Fetuin/alpha2-HS glycoprotein enhances phagocytosis of apoptotic cells and macropinocytosis by human macrophages. Clin Sci 2003, 105:273-278.

50. Nessim IG, Abd el Wahab A, Madani HA, Waked E, Abd el Khalek A, Mabrouk K: Evaluation of serum osteoprotegerin and fetuin A levels in Egyptian patients with chronic kidney disease. Comp Clin Pathol 2011, 20 (5):421-425.

51. Mehrotra R, Westenfeld R, Christenson P, Budoff M, Ipp E, Takasu J, Gupta A, Norris K, Ketteler M, Adler S: Serum fetuin-A in nondialyzed patients with diabetic nephropathy: relationship with coronary artery calcification. Kidney Int 2005, 67:1070-1077.

52. Schafer C, Heiss A, Schwarz A, Westenfeld R, Ketteler M, Floege J, Muller-Esterl W, Schinke T, Jahnen-Dechent W: The serum protein alpha 2-Heremans-Schmid glycoprotein/fetuin-A is a systemically acting inhibitor of ectopic calcification. J Clin Invest 2003, 112:357-366.

53. Ketteler M, Bongartz $P$, Westenfeld R, Wildberger JE, Mahnken AH, Böhm R, Metzger T, Wanner C, Jahnen-Dechent W, Floege J: Association of low fetuin-A (AHSG) concentrations in serum with cardiovascular mortality in patients on dialysis: a cross-sectional study. Lancet 2003, 361:827-833.

54. Wang AY, Woo J, Lam CW, Wang M, Chan IH, Gao P, Lui SF, Li PK, Sanderson JE: Association of serum fetuin-A with malnutrition, inflammation, atherosclerosis and valvular calcification syndrome and outcome in peritoneal dialysis patients. Nephrol Dial Transplant 2005, 20:1676-1685

55. Jono S, McKee MD, Murry CE, Shioi A, Morii HO: Phosphate regulation of vascular smooth muscle cell calcification. Circ Res 2000, 87:E10-E17.

56. Amann K: Media calcification and intima calcification are distinct entities in chronic kidney disease. Clin J Am Soc Nephrol 2008, 6:1599-1605

57. Zhang J1, Fu M, Myles D, Zhu X, Du J, Cao X, Chen YE: PDGF induces osteoprotegerin expression in vascular smooth muscle cells by multiple signal pathways. FEBS Lett 2002, 521:180-184.

58. Nitta K1, Akiba T, Uchida K, Otsubo S, Takei T, Yumura W, Kabaya T, Nihei H: Serum osteoprotegerin levels and the extent of vascular calcification in haemodialysis patients. Nephrol Dial Transplant 2004, 19:1886-1889.

59. Morena M, Terrier N, Jaussent I, Leray-Moragues H, Chalabi L, Rivory JP, Maurice F, Delcourt C, Cristol JP, Canaud B, Dupuy AM: Plasma osteoprotegerin is associated with mortality in hemodialysis patients. J Am Soc Nephrol 2006, 17(1):262-270

60. Matsubara K, Stenvinkel P, Qureshi AR, Carrero JJ, Axelsson J, Heimbürger O, Bárány P, Alvestrand A, Lindholm B, Suliman ME: Inflammation modifies 
the association of osteoprotegerin with mortality in chronic kidney disease. Am Soc Nephrol 2006, 17:262-270.

61. Basalyga DM, Simionescu DT, Xiong W, Baxter BT, Starcher BC, Vyavahare NR: Elastin degradation and calcification in an abdominal aorta injury model: role of matrix metalloproteinases. Circulation 2004, 110:3480-3487.

62. Rysz J, Banach M, Stolarek RA, Mikhailidis DP, Cialkowska-Rysz A, Pokoca L, Piechota M, Baj Z: Serum metalloproteinases MMP-2, MMP-9 and metalloproteinase tissue inhibitors TIMP-1 and TIMP-2 in patients on hemodialysis. Int Urol Nephrol 2011, 43(2):491-498.

63. Jeziorska M: Transforming growth factor beta and CD105 expression in calcification and bone formation in human atherosclerotic lesions. $Z$ Kardiol 2001, 90(Suppl 3):23-26.

64. Nagano M, Fukami K, Yamagishi S, Ueda S, Kaida Y, Matsumoto T, Yoshimura J, Hazama T, Takamiya Y, Kusumoto T, Gohara S, Tanaka H, Adachi H, Okuda S: Circulating matrix metalloproteinase-2 is an independent correlate of proteinuria in patients with chronic kidney disease. Am J Nephrol 2008, 29:109.

65. Chen NX, O'Neill KD, Chen X, Kiattisunthorn K, Gattone VH, Moe SM: Activation of arterial matrix metalloproteinases leads to vascular calcification in chronic kidney disease. Am J Nephrol 2011, 34(3):211-219

66. Vaughan $A M$, Oram JF: $A B C A 1$ and $A B C G 1$ or $A B C G 4$ act sequentially to remove cellular cholesterol and generate cholesterol-rich HDL. J Lipid Res 2006, 47:2433-2443

67. Yvan-Charvet L1, Ranalletta M, Wang N, Han S, Terasaka N, Li R, Welch C, Tall AR: Combined deficiency of ABCA1 and ABCG1 promotes foam cell accumulation and accelerates atherosclerosis in mice. J Clin Invest 2007, 117(12):3900-3908.

68. Lawn RM, Wade DP, Garvin MR, Wang X, Schwartz K, Porter JG, Seilhamer JJ, Vaughan AM, Oram JF: The Tangier disease gene product $A B C 1$ controls the cellular apolipoprotein-mediated lipid removal pathway. J Clin Invest 1999, 104:R25-R31.

69. Kennedy MA, Barrera GC, Nakamura K, Baldán A, Tarr P, Fishbein MC, Frank J, Francone OL, Edwards PA: ABCG1 has a critical role in mediating cholesterol efflux to HDL and preventing cellular lipid accumulation. Cell Metab 2005, 1:121-131.

70. Deair G, Li Y, Liu D: Down regulation of cardiac renalase expression in CKD and protective effect of renalase in acute coronary syndrome. J Am Soc Nephrol 2007, 18:149A.

71. Desir GV: Renalase deficiency in chronic kidney disease, and its contribution to hypertension and cardiovascular disease. Curr Opin Nephrol Hypertens 2008, 17(2):181-185.

72. Malyszko J, Malyszko JS, Rysz J, Mysliwiec M, Tesar V, Levin-laina N, Banach M: Renalase, hypertension, and kidney - the discussion continues. Angiology 2013, 64(3):181-187.

73. Malyszko J, Malyszko JS, Mikhailidis DP, Rysz J, Zorawski M, Banach M: Hypertension and kidney disease: is renalase a new player or an innocent bystander? J Hypertens 2012, 30(3):457-462.

74. Wu Y, Xu J, Velazquez H, Wang P, Li G, Liu D, Sampaio-Maia B, QuelhasSantos J, Russell K, Russell R, Flavell RA, Pestana M, Giordano F, Desir GV: Renalase deficiency aggravates ischemic myocardial damage. Kidney Int 2011, 79(8):853-860

75. Xu J, Li G, Wang P, Velazquez H, Yao X, Li Y, Wu Y, Peixoto A, Crowley S, Desir GV: Renalase is a novel soluble monoamine oxidase that regulates cardiac function and blood pressure. J Clin Invest 2005, 115:1275-1280.

76. Malyszko J, Koc-Zorawska E, Banach M, Mysliwiec M: Letter on 'sodiumdependent modulation of systemic and urinary renalase expression and activity in the rat remnant kidney'. J Hypertens 2013, 31(6):1272-1273.

77. Moe SM, Chen NX: Pathophysiology of vascular calcification in chronic kidney disease. Circ Res 2004, 95:560-567

78. Giachelli CM, Speer MY, Li X, Rajachar RM, Yang H: Regulation of vascular calcification: roles of phosphate and osteopontin. Circ Res 2005, 96:717-722

79. Franczyk-Skóra B, Gluba A, Banach M, Rysz J: Treatment of non-STelevation myocardial infarction and ST-elevation myocardial infarction in patients with chronic kidney disease. Arch Med Sci 2013, 9(6):1019-1027.

80. Cagli K, Basar N, Cagli K, Armutcu F, Aylak F, Yalcinkaya A, Erden G, Kadirogullari E: Association of serum fetuin-A with valvular calcium concentration in rheumatic mitral valve disease. $J$ Heart Valve Dis 2010, 19(5):636-643.
81. Yilmaz N: Relationship between paraoxonase and homocysteine: crossroads of oxidative diseases. Arch Med Sci 2012, 8(1):138-153.

82. Pietrzak-Nowacka M, Safranow K, Bober J, Olszewska M, Birkenfeld B, Nowosiad M, Ciechanowski K: Calcium-phosphate metabolism parameters and erythrocyte $\mathrm{Ca}(2+)$ concentration in autosomal dominant polycystic kidney disease patients with normal renal function. Arch Med Sci 2013, 9(5):837-842.

doi:10.1186/1476-511X-13-135

Cite this article as: Gluba-Brzózka et al:: Markers of increased

cardiovascular risk in patients with chronic kidney disease. Lipids in Health and Disease 2014 13:135.

\section{Submit your next manuscript to BioMed Central and take full advantage of:}

- Convenient online submission

- Thorough peer review

- No space constraints or color figure charges

- Immediate publication on acceptance

- Inclusion in PubMed, CAS, Scopus and Google Scholar

- Research which is freely available for redistribution

Submit your manuscript at www.biomedcentral.com/submit
Ciomed Central 